\title{
PEMANFAATAN TEKNOLOGI INFORMASI DALAM RANGKA MEMBERANTAS TINDAK PIDANA KORUPSI SECARA ELEKTRONIK
}

\author{
F.H. Edy Nugroho \\ Fakultas Hukum Universitas Atma Jaya Jakarta \\ E-mail: idegraha@yahoo.co.id
}

\begin{abstract}
Eradication of corruption in repressive/enforcement/penal would be more effective if accompanied by efforts in preventive/precautionary/non penal. One of the sources of corruption that resulted in losses to the state and the country's economy is in terms of government procurement of goods and services. Efforts to prevent corruption in the procurement of government goods and services, as well as efforts to create good governance and free from corruption, collusion and nepotism in providing services to the public, is to utilize information and communication technology, in the form of egovernment and e-procurement, as part of efforts to eradicate corruption in Indonesia.
\end{abstract}

Key words: corruption, prevention, eradication, e-government, e-procurement.

\begin{abstract}
Abstrak
Pemberantasan tindak pidana korupsi secara represif/penindakan/penal akan lebih efektif apabila disertai dengan upaya secara preventif/pencegahan/non penal. Salah satu sumber korupsi yang mengakibatkan kerugian keuangan negara dan perekonomian negara adalah dalam hal pengadaan barang dan jasa pemerintah. Upaya mencegah tindak pidana korupsi dalam pengadaan barang dan jasa pemerintah, serta upaya untuk menciptakan pemerintahan yang baik serta bebas dari korupsi, kolusi dan nepotisme dalam memberikan pelayanan kepada masyarakat, adalah dengan memanfaatkan teknologi informasi dan komunikasi, yaitu berupa e-government dan e-procurement, sebagai bagian dari upaya untuk memberantas tindak pidana korupsi di Indonesia.
\end{abstract}

Kata Kunci: tindak pidana korupsi, pencegahan, pemberantasan, e-government, e-procurement.

Pendahuluan

Indeks Pesepsi Korupsi (IPK) yang dikeluarkan oleh Transparansi Internasional Indonesia (TII) pada tahum 2013 menunjukkan penurunan peringkat Indonesia dibandingkan tahun 2012. Pada tahun 2012 Indonesia berada di peringkat 110, sedangkan pada tahun 2013 berada di peringkat 118 dari 177 negara yang disurvei. Peringkat Indonesia berada di bawah negaranegara ASEAN seperti Singapura, Malaysia, Filipina dan Tahiland, dan bahkan di bawah Timor Leste. Pada tahun 2013 Indonesia mendapatkan skor yang sama dengan tahun 2012 yaitu $32 .{ }^{1}$

Tindak pidana korupsi menimbulkan dampak negatif yang besar bagi suatu bangsa. Oleh karena itu tindak pidana korupsi harus dibe- rantas hingga tuntas secara komprehensif. Pemberantasan tindak pidana korupsi perlu dilakukan melalui upaya pemberantasan secara represif/penindakan/penal dan secara preventif/ pencegahan/non penal. Pemberantasan tindak pidana korupsi tidak semata-mata hanya memusatkan perhatian pada penanganan terhadap kasus tindak pidana korupsi yang telah terjadi, tetapi juga harus diiringi dengan upaya untuk melakukan pencegahan agar tidak terjadi tindak pidana korupsi.

Pemberantasan tindak pidana secara represif/penindakan/penal dapat menanggulangi tindak pidana korupsi dan mengembalikan kerugian keuangan negara dan perekonomian negara dalam jumlah yang lebih sedikit, jika diban-

Lihat di website: http://www.antikorupsi.org/id/con tent/indonesia-terkorup-No.-36-survei-transparency international, diakses pada taggal 2 Mei 2014. 
dingkan dengan tindakan secara preventif/pencegahan/non penal, yang dapat mencegah potensi kerugian keuangan negara dan kerugian perekonomian negara dalam jumlah yang lebih besar.

Perkembangan teknologi, khususnya teknologi sistem informasi dan komunikasi, memungkinkan untuk dilakukannya upaya pencegahan tindak pidana korupsi dengan memanfaatkan penerapan teknologi tersebut, atau dengan kata lain tindak pidana korupsi dapat dicegah secara elektronik. Penerapan teknologi sistem informasi dan komunikasi tersebut, diharapkan dapat memberikan kontribusi yang signifikan bagi pemberantasan tindak pidana korupsi di Indonesia, khsususnya dalam pengadaan barang dan jasa pemerintah dengan menggunakan e-procurement, serta penggunaan teknologi informasi oleh pemerintah (e-government) untuk memberikan informasi dan pelayanan bagi warganya, urusan bisnis, serta hal-hal lain yang berhubungan dengan pemerintahan.

Berdasarkan uraian tersebut di atas, maka dalam tulisan ini akan dibahas: petama, bagaimana upaya pemberantasan tindak pidana korupsi yang dapat dilakukan; kedua, bagaimana pemanfaatan teknologi informasi dalam rangka memberantas tindak pidana korupsi secara elektronik.

\section{Pembahasan}

Tindak Pidana Korupsi dan Upaya Pemberantasannya

Korupsi merupakan salah satu masalah terbesar yang dihadapi oleh bangsa Indonesia sampai saat ini. Upaya pemberantasa tindak pidana korupsi yang telah dilakukan di Indonesia cenderung parsial dan tidak didukung dengan desain strategi yang komprehensif untuk memberantas tindak pidana korupsi secara signifikan.

Waterbury memberikan definisi tentang korupsi sebagai berikut: "corruption is the abuse of public power and influence for privat ends."2

John Waterbury, “New Concepts for Old ?", Third World Quarterly Journal, Vol. 20, No. 3, 1999, London: Routledge, hlm. 13. (korupsi adalah penyalahgunaan kekuasaan publik dan pengaruh untuk tujuan-tujuan pribadi).

Tingginya tingkat korupsi di Indonesia mengindikasikan bahwa tindak pidana korupsi di Indonesia telah meluas pada berbagai bidang kehidupan masyarakat serta telah berlangsung dalam jangka waktu yang lama, sehingga mengakibatkan terjadinya kumulasi kerugian keuangan negara dan kerugian perekonomian negara dalam jumlah yang besar. Tindak pidana korupsi tidak hanya mengakibatkan kerugian keuangan negara dan perekonomian negara saja, tetapi juga berpengaruh terhadap tingkat kesejahteraan masyarakat serta terhambatnya pembangunan nasional.

Korupsi di Indonesia dapat dianggap sebagai hypercorruption, dimana terjadi gabungan antara state capture dan administrative corrupttion. Secara umum gejala ini ditandai dengan beradanya Indonesia dalam peringkat atas negara dengan tingkat korupsi yang tinggi.

Pemahaman terhadap gejala korupsi di Indonesia akan mempermudah cara mengatasinya guna memperbaiki strategi yang selama ini telah dilakukan. Pengalaman selama ini menunjukkan bahwa pembentukan lembaga anti korupsi yang merupakan bagian dari program anti korupsi saja akan sulit untuk mengatasi hypercorruption. Suatu strategi nasional berupa gerakan masyarakat dengan mengikutsertakan masyarakat luas (civil society) yang secara aktif berfungsi sebagai co-government akan memberi peluang yang lebih besar untuk memerangi hypercorruption. Selain itu, dalam jangka panjang perlu dikembangkan budaya transparansi dan akuntabilitas pada masyarakat luas. ${ }^{3}$

Strategi anti korupsi yang baik adalah strategi yang telah mempertimbangkan semua faktor yang berpengaruh, serta dengan melakukan diagnose yang benar terhadap permasalahan korupsi yang dihadapi. Strategi anti korupsi juga harus diarahkan pada penguatan peran masyarakat dalam mengawasi pemerintah serta penguatan publik dan partisipasi masyarakat da-

\footnotetext{
Iwan Gardono Sujatmiko, "Hypercorruption dan Strategi Pemberantasan Korupsi”, Jurnal Kriminologi Indonesia, Vol. 2, No. 1, Januari 2002, Jakarta: Universitas Indo-
} nesia, hlm. 25. 
lam pemberantasan korupsi. Akuntabilitas publik dan partisipasi masyarakat merupakan instrumen yang penting dalam menanggulangi korupsi. $^{4}$

Korupsi adalah kejahatan kalkulasi yang menggunakan pikiran, dan bukan kejahatan yang didorong oleh emosi. Seorang pejabat yang jujur dan mampu menolak suap, jika suap yang ditawarkan jumlahnya besar sedangkan kemungkinan tertangkapnya sangat kecil, dan jika tertangkap sanksi yang dijatuhkan sangat ringan, maka akan banyak pejabat yang tergoda untuk menerima suap. Oleh karena itu penanggulangan korupsi harus melalui sebuah sistem. Monopoli harus dikikis dan dilenyapkan, batas-batas wewenang harus jelas, akuntabilitas harus ditingkatkan, kemungkinan tertangkap tangan harus diperbesar, dan hukum bagi pelaku tindak pidana korupsi harus diperberat. ${ }^{5}$

Pemahaman terhadap aspek-aspek korupsi serta penyebabnya, dalam konteks situasi tertentu, menjadikan reformasi anti korupsi dapat dilakukan. Gerakan ini melalui proses dua tahap. Pertama, merumuskan kebijaksanaan untuk menangani penyebab-penyebab pokok korupsi. Kedua, menciptakan dan menumbuhkan kemauan politik (political will) yang sangat krusial bagi implementasi gerakan reformasi antikorupsi.

Kedua tahap tersebut mencerminkan peranan penting pemerintah dan birokrasi dalam gerakan anti korupsi. Gerakan ini membutuhkan good governance yang demokratis, kredibel, akuntabel dan transparan dalam mengelola sektor publik. Oleh Karena itu langkah awal yang paling penting adalah untuk meningkatkan tuntutan-tuntutan reformasi pada level pemerintahan, lalu di level masyarakat bisnis dan kemudian level publik. ${ }^{6}$

4 Teguh Kurniawan, "Peranan Akuntabilitas Publik dan Partisipasi Masyarakat dalam Pemberantasan Korupsi Pemerintahan", Bisnis dan Birokrasi, Jurnal Ilmu Administrasi dan Organisasi, Vol. 16, No. 2, 2009, Jakarta: FISIP UI, hlm. 120.

5 Siti Fatimah, "Korupsi: Menelusuri Akar Persoalan dan Menemukan Alternatif Pemecahannya", e-Journal.unp. ac.id, Demokrasi, Vol. 8, No. 2, 2007, Padang: Fakultas Ilmu Sosial Politik, Universitas Negeri Padang. hlm. 31.

6 Azyumardi Azra, "Korupsi dalam Prespektif Good Governance", Jurnal Kriminologi Indonesia, Vol. 2 No. 1, 2002, Jakarta: Universitas Indonesia, hlm. 33.

\section{Upaya Mencegah Tindak Pidana Korupsi Mela- lui E-Government}

Teknologi informasi dan komunikasi merupakan salah satu teknologi yang berkembang dengan sangat pesat. Pesatnya perkembangan teknologi informasi dan komunikasi akan menciptakan (to create), mengakses (to access), mengolah (to process), dan memanfaatkan (to uti(ize) informasi secara tepat dan akurat. Informasi merupakan suatu komoditi yang sangat berharga di era globalisasi untuk dikuasai dalam rangka meningkatkan daya saing suatu organisasi secara berkelanjutan. ${ }^{7}$

Pemerintahan di seluruh dunia pada saat ini menghadapi tekanan dari berbagai pihak untuk meningkatkan kualitas pelayanan publik dan meningkatkan partisipasi aktif dalam pemberian informasi bagi masyarakat serta dituntut untuk lebih efektif. Hal tersebut menyebabkan e-Government atau pemerintahan berbasis elektronik semakin berperan penting bagi semua pengambil keputusan. Pemerintah Tradisional (traditional government) yang identik dengan paper-based administration mulai ditinggalkan. Transformasi dari traditional government menjadi electronic government (e-Government) menjadi salah satu isu kebijakan publik yang hangat dibicarakan belakangan ini. ${ }^{8}$

Pemerintah Indonesia dalam menjawab tantangan tersebut, telah berinisiatif membuat kebijakan untuk memanfaatkan teknologi informasi dan komunikasi untuk membangun Electronic Government for Good Governance yang terintegrasi dari mulai pemerintahan daerah hingga ke pusat. Tujuannya supaya infrastruktur teknologi informasi dan komunikasi yang akan dibangun dapat dimanfaatkan secara bersama untuk melakukan koordinasi terhadap seluruh instansi, baik di pusat maupun di daerah.

7 Zainal A. Hasibuan, "Langkah-Langkah Strategis dan Taktis Pengembangan E-Government untuk Pemda", Jurnal Sistem Informasi, Vol. 3, No. 1, 2007, Jakarta: Magister Teknologi Informasi (MTI) Universitas Indonesia, hlm. 1.

8 Erick.S. Holle, "Pelayanan Publik Melalui Electronic Government: Upaya Meminimalisir Praktik Maladministrasi dalam Meningkatkan Public Service", Jurnal Sasi, Vol. 17, No. 3, Bulan Juli-September 2011, Ambon: FH Universitas Pattimura, hlm 21. 
Kebijakan pemerintah tersebut antara lain dituangkan dalam bentuk Instruksi Presiden (Inpres) Nomor 3 Tahun 2003 dan Keputusan Menteri Komunikasi dan Informasi tentang Pengembangan $e-G o v$ yang merupakan wujud keinginan pemerintah dalam upaya mendorong bangsa Indonesia menuju masyarakat yang berbasis pengetahuan (Knowledge-based Society). Instruksi Presiden Nomor 3 Tahun 2003 tentang Kebijakan dan Strategi Nasional Pengembangan e-Gov Indonesia, antara lain berisikan panduan yang sudah disosialisasikan, diantaranya sebagai berikut. Pertama, Panduan pembangunan infrastruktur portal pemerintah; kedua, Panduan manajemen sistem dokumen elektronik; ketiga, Panduan penyusunan rencana induk pengembangan e-Gov lembaga; keempat, Panduan penyelenggaraan situs web pemerintah daerah; dan kelima, Panduan tentang pendidikan dan pelatihan SDM e-Gov. Kebutuhan akan tersedianya informasi dari berbagai panduan tersebut, sekurang-kurangnya akan memiliki sifat-sifat antara lain: cakupannya luas, mudah digunakan, terkini, aman, serta murah.

E-Government pada dasarnya memberikan layanan informasi kepada sesama institusi pemerintah (Government to Government-G2G), kepada dunia bisnis (Government to Business-G2B) dan kepada masyarakat (Government to Citizen - G2C), dengan tujuan sebagai yaitu: mampu memberikan informasi lengkap mengenai lembaga atau daerah untuk kemajuan ekonomi dan pembangunan daerah, dan peningkatan kinerja proses pelayanan (peningkatan efektivitas dan produktivitas); dan mampu mengoptimalkan penggunaan sumber daya (resources) seperti waktu, tenaga, budget, dan fasilitas lainnya (peningkatan efisiensi). ${ }^{9}$

Praktik maladministrasi dapat terjadi dari kegiatan pelayanan publik yang diberikan para pejabat publik kepada warga masyarakat. Praktik maladministrasi cenderung terjadi pada pelayanan publik yang disediakan dengan cara kontak langsung antara penyedia layanan de- ngan pengguna jasa layanan. Melalui penerapan e-Government dapat dicegah terjadinya praktik maladministrasi seperti kolusi dan nepotisme, penyalahgunaan wewenang, permintaan imbalan uang, suap, dan bentuk praktik-praktik maladministrasi lainnya. ${ }^{10}$

\section{Upaya Mencegah Tindak Pidana Korupsi Mela- lui E-Procurement}

Pelayanan pengadaan barang dan jasa di lingkungan instansi pemerintah saat ini mulai dikembangkan penggunaan electronic procurement (e-procurement). Dengan menggunakan $e$ procurement, maka maladministrasi, seperti persekongkolan antara pengusaha (pelaku tender) dengan oknum panitia tender tidak terjadi lagi. ${ }^{11}$

Salah satu kegiatan pemerintah yang memungkinkan terjadinya tindak pidana korupsi atau kolusi, korupsi, dan nepotisme (KKN) adalah pengadaan barang dan jasa pemerintah. Pengadaan barang dan jasa pada hakekatnya adalah kegiatan untuk memperoleh barang dan jasa oleh Kementerian/Lembaga/Satuan Kerja Perangkat Daerah/Institusi lainnya yang prosesnya dimulai dari perencanaan kebutuhan sampai diselesaikannya seluruh kegiatan untuk memperoleh barang dan jasa. ${ }^{12}$

Pengadaan barang dan jasa pada dasarnya adalah upaya pihak pengguna untuk mendapatkan atau mewujudkan barang dan jasa yang diinginkannya dengan menggunakan metode dan proses tertentu agar dicapai kesepakatan harga, waktu dan kesepakatan lainnya. Agar hakekat atau esensi pengadaan barang dan jasa tersebut dapat dilaksanakan sebaik-baiknya, maka kedua belah pihak yaitu pihak pengguna dan penyedia haruslah selalu berpatokan kepada filosofi pengadaan barang dan jasa, tunduk kepada etika dan norma pengadaan barang dan jasa yang baku. Dimana proses pengadaan barang dan jasa di Indonesia diatur dalam Peraturan Presiden No.

\footnotetext{
Zainal A. Hasibuan, op.cit., hlm. 1

Erick.S. Holle, op.cit., hlm 24-26.

Ibid., hlm 26.
}

12 Endang Asliana, "Pengadaan Barang dan Jasa di Indonesia”, Jurnal Ilmian ESAI, Vol. 6, No. 1, Januari 2012, Lampung: Jurusan Ekonomi dan Bisnis, Politeknik Negeri Lampung, hlm. 22. 
54 Tahun 2010 tentang Pengadaan Barang dan Jasa Pemerintah. ${ }^{13}$

\section{E-Procurement (Electronic Procurement)} merupakan proses pengadaan barang dan jasa yang meliputi pengumuman pelelangan, permintaan spesifikasi barang dan jasa beserta harga, negosiasi atau tawar menawar harga, lelang, pemesanan barang dan jasa (terbentuknya purchase order), dan keterangan status pengiriman barang dan jasa, yang dilakukan secara online menggunakan teknologi internet, ${ }^{14}$ yang diselenggarakan oleh Layanan Pengadaan Secara Elektronik (LPSE).

Dasar hukum pembentukan Layanan Pengadaan Secara Elektronik (LPSE) adalah Pasal 111 Peraturan Presiden Nomor 54 Tahun 2010 tentang Pengadaan Barang dan Jasa Pemerintah, yang ketentuan teknis operasionalnya diatur dalam Peraturan Kepala Lembaga Kebijakan Pengadaan Barang dan Jasa Pemeritah (LKPP) ${ }^{15}$ No2 Tahun 2010 tentang Layanan Pengadaan Secara Elektronik. Layanan Pengadaan Secara Elektronik (LPSE) dalam menyelenggarakan sistem pelayanan pengadaan barang dan jasa juga wajib memenuhi persyaratan sebagaimana yang ditentukan dalam Undang-undang Nomor $11 \mathrm{Ta}$ hun 2008 tentang Informasi dan Transaksi Elektronik.

Lembaga Kebijakan Pengadaan Barang/ Jasa Pemerintah (LKPP) merupakan Lembaga Pemerintah Non Departemen yang berada di bawah dan bertanggung jawab kepada Presiden dan dibentuk berdasarkan Peraturan Presiden No. 106 Tahun 2007. LKPP merupakan lembaga pemerintah satu-satunya yang mempunyai tugas melaksanakan pengembangan dan perumusan kebijakan pengadaan barang/jasa pemerintah, dan dalam melaksanakan tugas dan fungsinya LKPP dikoordinasikan oleh Menteri Negara Perencanan Pembangunan Nasional.

Layanan yang tersedia dalam Sistem Secara Elektronik diantaranya adalah e-tendering, yang ketentuan teknis operasionalnya diatur de-

$13 \quad$ Ibid, hlm. 22.

14 Humisar Hasugian, "Kajian Penerapan E-Procurement Industri Konstruksi: Studi Kasus pada P.T. Rekayasa Industri”, Jurnal Telematika MKOM, Vol. 2, No. 2, September ngan Peraturan Kepala Lembaga Kebijakan Pengadaan Barang dan Jasa Pemeritah (LKPP) No. 18 Tahun 2012 tentang Tata Cara E-Tendering. Selain itu Lembaga Kebijakan Pengadaan Barang dan Jasa Pemeritah (LKPP) juga menyediakan fasilitas katalog elektronik (e-catalog), yaitu sistem informasi elektronik yang memuat daftar, jenis, spesifikasi teknis dan harga barang tertentu dari berbagai penyedia barang dan jasa pemerintah, proses audit secara online (eaudit), dan tata cara pembelian barang dan jasa melalui katalog elektronik (e-purchasing).

Sistem Pengadaan Secara Elektronik (SP$\mathrm{SE})$ merupakan aplikasi e-procurement yang dikembangkan oleh Direktorat e-Procurement Lembaga Kebijakan Pengadaan Barang dan Jasa Pemeritah (LKPP) untuk digunakan oleh Layanan Pengadaan Secara Elektronik (LPSE) di seluruh Kementerian/Lembaga/Satuan Kerja Perangkat Daerah/Institusi lainnya (K/L/D/I). Aplikasi tersebut dikembangkan dengan semangat efisiensi nasional, sehingga tidak memerlukan biaya lisensi, baik lisensi Sistem Pengadaan Secara Elektronik (SPSE), maupun perangkat lunak pendukungnya. Sistem Pengadaan Secara Elektronik (SPSE) dikembangkan oleh Lembaga Kebijakan Pengadaan Barang dan Jasa Pemerintah (LKPP) bekerjasama dengan: Lembaga Sandi Negara (Lemsaneg) untuk fungsi enkripsi dokumen; dan Badan Pengawasan Keuangan dan Pembangunan (BPKP) untuk sub sistem audit. ${ }^{16}$

Prinsip-prinsip yang harus diterapkan dalam pengadaan barang dan jasa pemerintah sebagaimana tertuang pada penjelasan Pasal 5 Peraturan Presiden Nomor 54 Tahun 2010, adalah sebagai berikut. Pertama, efisien. Efisien pengadaan diukur terhadap seberapa besar upaya yang dilakukan untuk memperoleh barang dan jasa dengan spesifikasi yang sudah ditetapkan. Upaya yang dimaksud mencakup dana dan daya yang dikeluarkan untuk memperoleh barang dan jasa. Kedua, efektif. Efektivitas pengadaan diukur terhadap seberapa jauh barang dan jasa

2010, Jakarta: Program Pascasarjana Teknologi Informasi, Universitas Budi Luhur, hlm. 117.

15 Dikutip dari http://www.lpse.jakarta.go.id/eproc/ten tangkami, diakses pada tanggal 29 Mei 2014.

16 Ibid. 
yang diperoleh dari proses pengadaan dapat mencapai spesifikasi yang sudah ditetapkan. Ketiga, transparan. Bagaimana proses pengadaan barang dan jasa dilakukan dapat diketahui secara luas. Proses yang dimaksud meliputi dasar hukum, ketentuan-ketentuan, tata cara, mekanisme, aturan main, spesifikasi barang dan jasa, dan semua hal yang terkait dengan bagaimana proses penga-daan barang dan jasa dilakukan. Dapat diketahui secara luas berarti semua informasi tentang proses tersebut mudah diperoleh dan mudah diakses oleh masyarakat umum, terutama penyedia barang dan jasa yang berminat. Keempat, terbuka. Berarti pengadaan barang dan jasa dapat diikuti oleh semua orang penyedia barang dan jasa yang memenuhi persyaratan atau kriteria yang ditetapkan sesuai ketentuan yang berlaku. Kelima, bersaing: Proses pengadaan barang dapat menciptakan iklim atau suasana persaingan yang sehat diantara para penyedia barang dan jasa, tidak ada intervensi yang dapat mengganggu mekanisme, sehingga dapat menarik minat sebanyak mungkin penyedia barang dan jasa untuk mengikuti lelang atau seleksi yang pada gilirannya dapat diharapkan untuk memperoleh barang dan jasa dengan kualitas yang maksimal. Keenam, adil/tidak diskriminatif. Proses pengadaan dapat memberikan perlakuan yang sama bagi semua calon penyedia barang dan jasa dan tidak mengarah untuk memberikan keuntungan pada pihak tertentu, kecuali diatur dalam peraturan ini. Sebagai usaha bahwa dalam peraturan ini mengatur agar melibatkan sebanyak mungkin usaha kecil, usaha menengah dan koperasi kecil. Disamping itu juga mengutamakan produksi dalam negeri. Ketujuh, akuntabel. Harus sesuai dengan aturan dan ketentuan yang terkait dengan pengadaan barang dan jasa sehingga dapat dipertanggungjawabkan.

E-Procurement dapat menjadi instrumen untuk mengurangi tindakan korupsi, kolusi dan nepotisme (KKN), karena melalui e-procurement lelang menjadi terbuka, sehingga akan muncul penawaran-penawaran yang lebih rasional, bah- kan bagi peserta lelang yang tidak berada dalam jaringan juga dapat turut serta. ${ }^{17}$ Kebijakan implementasi e-procurement dilakukan dengan cara mengoptimalkan pemanfaatan kemajuan teknologi informasi untuk mewujudkan good governance melalui pengadaan barang dan jasa yang bebas dari korupsi, kolusi, dan nepotisme $(\mathrm{KKN}) .{ }^{18}$

E-procurement juga berdampak terhadap interaksi yang terjadi antara pelaku usaha dengan pemerintah. Jika di masa lalu, pelaku usaha perlu sering mendatangi instansi pemerintah di masing-masing sektor dan mendekati pihak yang terkait untuk mendapatkan informasi tentang peluang pengadaan, maka kini informasi tersebut telah tersedia dalam sistem. Akibatnya, terjadi perubahan cara berinteraksi dimana frekuensi komunikasi melalui sistem e-procurement meningkat sedangkan frekuensi tatap muka menjadi jauh berkurang. ${ }^{19}$

Manfaat lain dari e-procurement diantaranya adalah sebagai berikut. Pertama, meningkatkan transparansi dan akuntabilitas dalam pengadaan barang dan jasa pemerintah; kedua, menjamin persamaan kesempatan, akses dan hak yang sama bagi para pihak pelaku pengadaan barang dan jasa; ketiga, menciptakan situasi yang kondusif agar terjadi persaingan yang sehat antar penyedia barang dan jasa; keempat, menciptakan situasi yang kondusif bagi aparatur pemerintah dan menjamin terselenggaranya komunikasi online untuk mengurangi intensitas pertemuan langsung antara penyedia barang dan jasa dengan panitia pengadaan dalam mendukung pemerintahan yang besih dan bebas dari korupsi, kolusi dan nepotisme (KKN); kelima, memberi keadilan bagi seluruh peserta lelang, baik peserta dari penyedia barang dan jasa dengan kualifikasi kecil atau non kecil; keenam, memudahkan bagi peserta lelang untuk mengikuti semua tahapan lelang sesuai regulasi yang ada dengan pemanfaatan teknologi informasi (internet); dan

17 Kodar Udoyono, “E-Procurement dalam Pengadaan Barang dan Jasa untuk Mewujudkan Akuntabilitas di Kota Yogyakarta", Jurnal Studi Pemerintahan, Vol. 3, No. 1,

18 Ibid., hlm. 129-130.

Februari 2012, Yogyakarta: UMY, hlm. 128. 
ketujuh, mengurangi dan menekan biaya dari kedua belah pihak. ${ }^{20}$

Sistem e-procurement bukan merupakan sistem yang sempurna sepenuhnya untuk pengadaan barang dan jasa pemerintah, beberapa kendala atau kekurangan dari bekerjasanya sistem maupun personil yang mengoperasikan-nya perlu untuk diantisipasi, seperti misalnya: (a) Penyedia jasa dan pengguna jasa yang kurang memahami sistem e-procurement di Layanan Pengadaan Secara Elektronik (LPSE); (b) Koneksi internet yang kurang baik dapat menyulitkan proses download dan upload dokumen; (c) Pemadaman listrik oleh PLN yang dapat mengganggu pelayanan; (d) Minimnya sosialisasi kepada peserta lelang sehingga banyak yang tidak mengerti proses lelang dengan e-procurement; (e) Minimnya dukungan dari pimpinan daerah untuk mendukung Layanan Pengadaan Secara Elektronik (LPSE); ${ }^{21}$ (f) Kelemahan regulasi dalam pengadaan barang dan jasa pemerintah secara elektronik sulit diawasi oleh masyarakat dalam proses implementasi tender, karena dalam regulasi tidak ada pengaturan dalam monitoring pelaksanaan tender. Aparat pengawasan fungsional pemeritah sering kurang antisipatif dalam melaksanakan tugasnya, dan tim pengawas independen jarang dilibatkan, sehingga kerap muncul masalah, seperti misalnya : adanya sertifikasi perusahaan yang tidak fair, penggelembungan harga karena tidak ada institusi yang mengawasi tarif atau standar harga; (g) Pembentukan panitia pengadaan barang dan jasa merupakan langkah stratejik dan harus diwaspadai dalam proses pengadaan barang dan jasa, sebab berkembangnya korupsi, kolusi dan nepotisme (KKN) dalam proses pengadaan pemerintah sangat tergantung pada komitmen panitia lelang yang akan sangat berpengaruh terhadap bersih tidaknya proses pengadaan barang dan jasa di suatu unit kerja pemerintah. Beberapa masalah yang terkait dengan tahap ini adalah panitia ti-

20 I Made Suciptapura, I.G.A. Adnyana Putera, Mayun Nadiasa, "Partisipasi Kontraktor di Kota Denpasar dalam Lelang Pengadaan Barang dan Jasa Pemerintah Secara Elektronik", Jurnal Spektra, Vol. 2, No. 2, Juli 2013, Denpasa: Program Magister Teknik Sipil, Universitas Udayana, hlm. 23. dak transparan, integritas panitia lemah, panitia memihak atau tidak independen dengan cara menambah persyaratan untuk membatasi jumlah peserta; (h) Adanya kekuatan politik yang terlibat dalam proses pengadaan barang dan jasa secara elektronik, dalam bentuk peraturan perundang-undangan yang dikeluarkan oleh kepada daerah. Bentuk dukungan politik dilakukan dengan mengeluarkan suatu peraturan perundang-undangan dan mengevaluasi langsung jalannya e-procurement, serta adanya relasi politik antara para pejabat dengan pengusaha. ${ }^{22}$

Masyarakat memiliki peranan yang sangat penting untuk melakukan kontrol terhadap proses lelang, dimana dengan sistem yang terbuka dan mudah diakses. Masyarakat dapat menyampaikan keberatan apabila proses lelang tidak sesuai dengan prosedur atau terindikasi terjadi korupsi, kolusi dan nepotisme (KKN). ${ }^{23}$

\section{Penutup \\ Simpulan}

Tindak pidana korupsi merupakan salah satu masalah terbesar bagi bangsa Indonesia. Pemberantasan tindak pidana korupsi perlu dilakukan secara komprehensif baik secara penal/ penindakan maupun non penal/pencegahan, dengan melibatkan partisipasi masyarakat secara luas.

Teknologi informasi dan komunikasi merupakan salah satu teknologi yang berkembang dengan pesat, dan dapat dimanfaatkan untuk membantu mencegah tindak pidana korupsi. Melalui penerapan electronic government (e-governmet) dapat dicegah terjadinya maladministrasi dalam pelayanan publik, seperti korupsi, kolusi dan nepotisme $(\mathrm{KKN})$, penyalahgunaan wewenang, suap dan sebagainya. Pengadaan barang dan jasa di lingkungan instansi pemerintah yang sarat dengan korupsi, kolusi dan nepotisme (KKN) dapat pula dicegah dengan menerapkan electronic procurement (e-procurement). Se-

21 Edy Mulyono, Martoyo, Endang Indri Listiani, “Implementasi Pengadaan Barang dan Jasa Pemerintah Berdasarkan Peraturan Presiden No. 54 Tahun 2010", Jurnal Tesis PMIS, Pontianak: UNTAN-PSIAN-2013, hlm. 13-14

22 Kodar Udoyono, Op.Cit., hlm 141-145.

23 Edy Mulyono, Martoyo, Endang Indri Listiani, op.cit., hlm. 14. 
hingga penawaran menjadi lebih rasional, efisien, adil, transparan dan akuntabel.

\section{Saran}

Menciptakan pemerintahan yang baik, bersih dan bebas dari korupsi, kolusi dan nepotisme, melalui e-government, serta upaya pengadaan barang dan jasa secara elektronik melalui e-procurement, sudah selayaknya wajib diterapkan pada seluruh instansi pemerintah. Mulai dari pemerintahan pusat sampai daerah, serta pada lembaga-lembaga negara. Hal ini dilakukan sebagai bagian dari tindakan pencegahan terjadinya korupsi dalam rangka memberantas tindak pidana korupsi di Indonesia.

\section{Daftar Pustaka}

Azyumardi, Azra. "Korupsi dalam Prespektif Good Governance". Jurnal Kriminologi Indonesia. Vol. 2 No. 1 2002. Jakarta: Universitas Indonesia;

Endang, Asliana. "Pengadaan Barang dan Jasa di Indonesia". Jurnal Ilmian ESAI. Vol. 6 No. 1 Januari 2012. Lampung: Jurusan Ekonomi dan Bisnis. Politeknik Negeri Lampung;

Erick, S, Holle. "Pelayanan Publik Melalui Electronic Government: Upaya Meminimalisir Praktik Maladministrasi dalam Meningkatkan Public Service". Jurnal Sasi. Vol. 17. No. 3. Bulan Juli-September 2011. Ambon: Fakultas Hukum. Universitas Pattimura;

Fatimah, Siti. "Korupsi: Menelusuri Akar Persoalan dan Menemukan Alternatif Pemecahannya". e-Journal.unp.ac.id. Demokrasi. Vol. VI. No. 1 2007. Padang: Fakultas Ilmu Sosial Politik. Universitas Negeri Padang;

Hasugian, Humisar. "Kajian Penerapan E-Procurement Industri Konstruksi: Studi Kasus pada P.T. Rekayasa Industri”. Jurnal Tele- matika MKOM. Volume 2. Nomor 2. September 2010. Jakarta: Program Pascasarjana Teknologi Informasi. Universitas Budi Luhur;

Kurniawan, Teguh. "Peranan Akuntabilitas Publik dan Partisipasi Masyarakat dalam Pemberantasan Korupsi Pemerintahan". Bisnis dan Birokrasi. Jurnal Ilmu Administrasi dan Organisasi. Vol. 16 No. 2 2009. Jakarta: Fakultas Ilmu Sosial dan Ilmu Politik. Universitas Indonesia;

Mulyono, Edy. Martoyo. Endang Indri Listiani. "Implementasi Pengadaan Barang dan Jasa Pemerintah Berdasarkan Peraturan Presiden Nomor 54 Tahun 2010". Jurnal Tesis PMIS. 2013. Pontianak: UNTANPSIAN;

Suciptapura I, Made. I.G.A. Adnyana Putera. Mayun Nadiasa. "Partisipasi Kontraktor di Kota Denpasar dalam Lelang Pengadaan Barang dan Jasa Pemerintah Secara Elektronik". Jurnal Spektra. Vol. 2 No. 2 Juli 2013. Denpasar: Program Magister Teknik Sipil. Universitas Udayana;

Sujatmiko, Iwan Gardono. "Hypercorruption dan Strategi Pemberantasan Korupsi”. Jurnal Kriminologi Indonesia. Vol. 2 No. 1 Januari 2002. Jakarta: Universitas Indonesia;

Udoyono, Kodar. "E-Procurement dalam Pengadaan Barang dan Jasa untuk Mewujudkan Akuntabilitas di Kota Yogyakarta". Jurnal Studi Pemerintahan. Vol. 3 No. 1 Februari 2012. Yogyakarta: Universitas Muhammadiyah Yogyakarta;

Waterbury, John. "New Concepts for Old ?". Third World Quarterly Journal. Vol. 20 No. 3 tahun 1999. London: Roudledge;

Zainal, A, Hasibuan. "Langkah-Langkah Strategis dan Taktis Pengembangan E-Government untuk Pemda". Jurnal Sistem Informasi. Volume 3. Nomor 1. 2007. Jakarta: Magister Teknologi Informasi (MTI) Universitas Indonesia. 